\title{
CD70 Antigen
}

National Cancer Institute

\section{Source}

National Cancer Institute. CD70 Antigen. NCI Thesaurus. Code C104079.

CD70 antigen (193 aa, $\sim 21 \mathrm{kDa}$ ) is encoded by the human CD70 gene. This protein is

involved in T-cell activation and proliferation and may also play a role in B-cell activation. 